\title{
A DIFERENÇA RESISTE À DE(S)MOCRATIZAÇÃO ${ }^{1}$
}

\author{
Thalles do Amaral de Souza Cruz
}

Mestrado e Doutorado em Educação pela UERJ. Atualmente é professor substituto de Didática na Faculdade de Educação da UFRJ, pesquisador do Grupo de Estudos sobre Gênero, Sexualidade e Interseccionalidades na Educação e na Saúde (GENI) e do Grupo de Estudos e Pesquisas Currículo, Subjetividade e Diferença, ambos no ProPEd/UERJ. thallesamaral@yahoo.com.br https://orcid.org/0000-0002-7025-6971

\section{Elizabeth Macedo}

Mestrado e Doutorado em Educação respectivamente pela UFRJ e UNICAMP. Pós-doutorado pela University of British Columbia. Professora titular da UERJ. Coordena o Grupo de Pesquisa Currículo, Cultura e Diferença do CNPq. Suas pesquisas em andamento têm se concentrado em mapear as redes de demandas (ou de poder) em ação durante a elaboração de currículos nacionais, bem como como durante os processos de implementação nos estados.bethmacedo@pobox.com

\section{RESUMO}

A legitimação, principalmente a partir de processos eleitorais, de discursos antidemocráticos, explicitamente discriminatórios, excludentes e autoritários tem nos levado a um período pósdemocrático ou ainda de de(s)mocratização, o que afeta também o campo educacional. Neste texto, analisamos políticas públicas educacionais brasileiras dos últimos anos - entendidas aqui também como políticas de subjetivação ou como prática de governamentalização - que reiteraram uma tradição educacional baseada nos Direitos Humanos, estando assim na defesa e construção da democracia. Argumentamos que tais políticas têm se constituído como alvos principais de uma racionalidade neoliberal antidemocrática, expressa numa rede de articulação de demandas do capital de atores religiosos conservadores, assim como de grupos militares. Dessa forma, além de significarmos as recentes ações conservadoras como uma reação à implementação de políticas redistributivas e de reconhecimento da alteridade, buscamos entender o projeto que tentam hegemonizar. Assumimos que o caráter incontrolável do processo de significação ou do processo ensino-aprendizagem, incorporado de certa forma por aquelas políticas públicas para diferença, tornam-se aqui um obstáculo inquebrantável para a nova agenda, atuando politicamente como uma resistência política e ontológica.

Palavras-chave: currículo, diferença, democracia, gênero

\section{THE DIFFERENCE RESISTS DE(S)MOCRATIZATION}

\begin{abstract}
The legitimization, especially from electoral processes, of anti-democratic, explicitly discriminatory, exclusionary and authoritarian discourses has led us to a post-democratic or even a de(s)mocratization period, which also affects the educational field. In this paper, we analyze last years Brazilian educational public policies - understood here also as subjectivation policies, or as a practice of governmentalization - that reiterated an educational tradition based on Human Rights, thus acting in the defense and construction of democracy. We argue that such policies have become the main targets of anti-democratic neoliberal rationality, expressed in a network that articulates demands from capital, conservative religious actors, as well as military groups. Thus, in addition to analyze recent conservative actions as a reaction to the implementation of redistributive policies, as well as of policies that recognize alterity, we seek to understand the project that they attempt to hegemonize. We assume that the uncontrollable character of the process of signification (or of the teaching-learning process), incorporated in a certain way by those public policies for difference,
\end{abstract}

\footnotetext{
${ }^{1}$ Este texto está vinculado à tese de doutorado de Thalles do Amaral de Souza Cruz, orientada por Elizabeth Macedo e financiada pela FAPERJ. Articula-se, também, a projeto financiado pela mesma agência no Edital Cientista do Nosso Estado e pelo Programa Prociência da UERJ.
} 
become here an unbreakable obstacle to the new agenda, acting as political and ontological resistance.

Keywords: curriculum, difference, democracy, gender

\section{LA DIFERENCIA RESISTE A LA DE(S)MOCRATIZACIÓN}

\section{RESUMEN}

La legitimación, principalmente a partir de procesos electorales, de discursos antidemocráticos, explícitamente discriminatorios, excluyentes y autoritarios nos ha llevado a un período postdemocrático o de mera de(s)mocratización, lo que afecta también al campo educativo. En este texto, analizamos políticas públicas educativas brasileñas de los últimos años - entendidas aquí también como políticas de subjetivación, o aún, como práctica de gobernanza - que reiteraron una tradición educativa basada en los Derechos Humanos, estando así en la defensa y construcción de la democracia. Argumentamos que tales políticas se han constituido como objectivos principales de una racionalidad neoliberal antidemocrática, expresada en una red de articulación de demandas del capital, de actores religiosos conservadores, así como de grupos militares. De esta forma, además de significar las recientes acciones conservadoras como una reacción a la implementación de políticas redistributivas y de reconocimiento de la alteridad, buscamos entender el proyecto que intentan hegemonizar. Se asume que el carácter incontrolable del proceso de significación o del proceso de enseñanza aprendizaje, incorporado, en cierto modo, por aquellas políticas públicas a diferencia, se convierten en un obstáculo inquebrantable para la nueva agenda, actuando políticamente como una resistencia política y ontológica.

Palabras-clave: currículo, diferencia, democracia, género

\section{Introdução}

A legitimação de discursos antidemocráticos, explicitamente discriminatórios, excludentes e autoritários, principalmente a partir de processos eleitorais, tem nos levado a um período pós-democrático ou ainda de de(s)mocratização, o que afeta também o campo educacional. $\mathrm{O}$ fortalecimento de tais discursos vem ocorrendo em diversas democracias ocidentais, desde as mais frágeis até as mais consolidadas. No contexto da América Latina, tem havido o fortalecimento de uma cruzada moral conservadora principalmente contra qualquer tipo de educação sexual ou algum aspecto da educação escolar que venha apontar a historicidade das questões sociais envolvendo o marcador social de gênero. Assim, se por um lado políticas públicas igualitárias em diversos países desta região, inclusive o Brasil, buscaram trabalhar no combate às desigualdades sociais fortemente atravessadas por marcadores sociais da diferença mediante uma perspectiva interseccional, os ataques a essas políticas também têm se utilizado da interseccionalidade desses mesmos marcadores para criar obstáculos à sua realização. Podemos citar como exemplo o caso do Acordo de Paz na Colômbia, que interseccionou questões identitárias político-partidárias com questões ligadas às práticas da religiosiade afro-cubana, para classificar tal acordo como algo ligado a um plano "comunista diabólico". 
O dispositivo da infância/juventude, ao ser utilizado pelo conservadorismo para colocar crianças e jovens como figuras sempre indefesas e passivas (LEITE, 2013), tem contribuído para propagar mais rapidamente pânicos morais, mas concomitantemente para fortalecer uma racionalidade neoliberal. Assim, ao significarem a arena escolar como um ambiente de risco para a preservação da moral conservadora, essas agendas internacionais de conservadorismo nos costumes e de recrudescimento neoliberal se unem para defender não só a retirada de tais temáticas da educação escolar como também a retirada do próprio Estado do campo educacional. Cabe ressaltar que isso não deixa de ser uma reação a um contexto de crescente atuação de políticas públicas e de pressão de movimentos sociais identitários para que determinadas questões geradoras de estigmas, discriminaçãoes e preconceitos sejam trabalhadas em sala de aula como uma forma de realmente se efetivar uma educação democrática.

No Brasil, a defesa da regulamentação da chamada "homeschooling" por tais grupos seria o maior símbolo da união dessas duas agendas. Caso a regulamentação seja aprovada, responsáveis conservadores/as não seriam mais obrigados/as a enviar seus/suas filhos/as para escolas e dessa forma "correr o risco" de entrar em contato com temáticas indesejáveis. Além disso, o Estado teria sua influência de governamentalizar nesse campo diminuída e se desobrigaria de financiar uma educação pública, já que agora toda e qualquer residência seria uma escola em potencial, cabendo a cada família se responsabilizar para garantir e chegar a uma educação de qualidade ${ }^{2}$. Isso reforçaria a lógica da competividade neoliberal, naturalizando também uma subjetividade individualista: a educação não teria mais em seu horizonte a preocupação com a socialização na diferença, tampouco com a justiça social, mas sim com a lógica do sucesso econômico individual.

No entanto, seja a agenda de conservadorismo moral, seja a agenda de fortalecimento da racionalidade neoliberal, resistências no campo da política e do político estão presentes. A inexorabilidade de tais resistências é entendida a partir da teoria do discurso (LACLAU, 2011), em que o social é definido como ontologicamente político porque marcardo pelo antagonismo. Já no nível ôntico, a política é entendida como sendo

\footnotetext{
${ }^{2}$ Entendida nessa lógica como a que alcança os níveis de excelência estipulados pelas avaliações internacionais, como o PISA, por exemplo, criadas e financiadas por organismos internacionais como Banco Mundial, OCDE etc. que, com base em critérios etnocêntricos, desconsideram toda a diversidade dos contextos onde tais testes são realizados, valorizando apenas o resultado final e o posicionamento no ranking internacional em uma lógica competitiva estéril.
} 
constituída por disputas por significações que não possuem fundamento último, mas sim articulações frente a exteriores constitutivos. Essas articulações visam à hegemonia (transformar algo que é particular em uma pretensa universalidade) que, por sua vez, será sempre precária, já que o caráter antagônico do social é incontornável. Assim, para além da posição política do conservadorismo moral e da racionalidade neoliberal que se viram ameçadas por ações políticas mais igualitárias nos últimos anos na América Latina - e que tentam retomar a hegemonia -, outros posicionamentos políticos antagônicos obstaculariza(ra)m tais planos. Foi o que aconteceu no Brasil, por exemplo, nas ocupações estudantis de diversas escolas públicas em várias regiões do país em 2015 para impedir o avanço de projetos como o Escola Sem Partido e o congelamento dos investimentos públicos no setor por 20 anos.

Nesse sentido, então, defendemos que a diferença resiste à de(s)mocratização. Isso não significa dizer que a diferença não seja afetada por tal processo ou que não haja grupos e regimes que visem implementar (ou que tenham implementado) ${ }^{3}$ políticas didatoriais, antidemocráticas. O que queremos apontar é que a significação social de projetos políticos conservadores nunca será $100 \%$ aceita, já que o antagonismo é necessário para a constituição do prórprio discurso que o sustenta. Desse modo, outros agentes sociais estarão sempre se articulando em busca de uma nova hegemonia. Portanto, a resistência não é contingente, mas sim ontológica, constituindo a disputa na arena pública tanto em relação a projetos considerados progressistas/desconstrucionistas como àqueles projetos conservadores. Assim sendo, analisaremos como a racionalidade neoliberal antidemocrática - expressa numa rede de articulação de demandas do capital, de atores religiosos conservadores, assim como de grupos militares - tem se utilizado de uma moral sexual e econômica para atacar não só o Estado como também o próprio regime democrático, o que tem trazido fortes reflexos no campo educacional.

\section{O que cabe no combate à ideologia de gênero}

\footnotetext{
${ }^{3}$ Se analisarmos o passado recente de diversos países da América Latina, por exemplo, encontraremos diversos regimes políticos ditatoriais em que a oposição política aos governos nacionais era combatida com sequestros, torturas e assassinatos.
} 


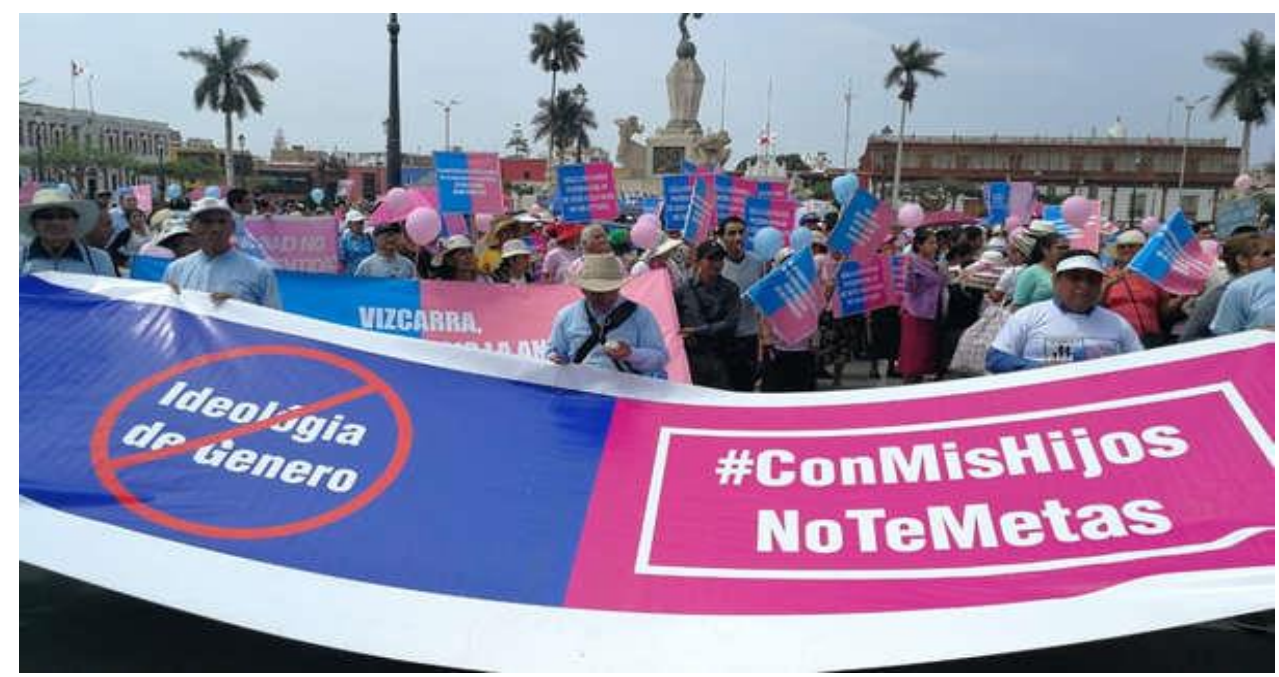

Figura 1: Marcha do movimento Con mis Hijos no te Metas pelas ruas do centro histórico de Trujillo, Peru, em $15 / 11 / 2018$.

Fonte: RPP Notícias. Acesso em 6 mar. 2019.

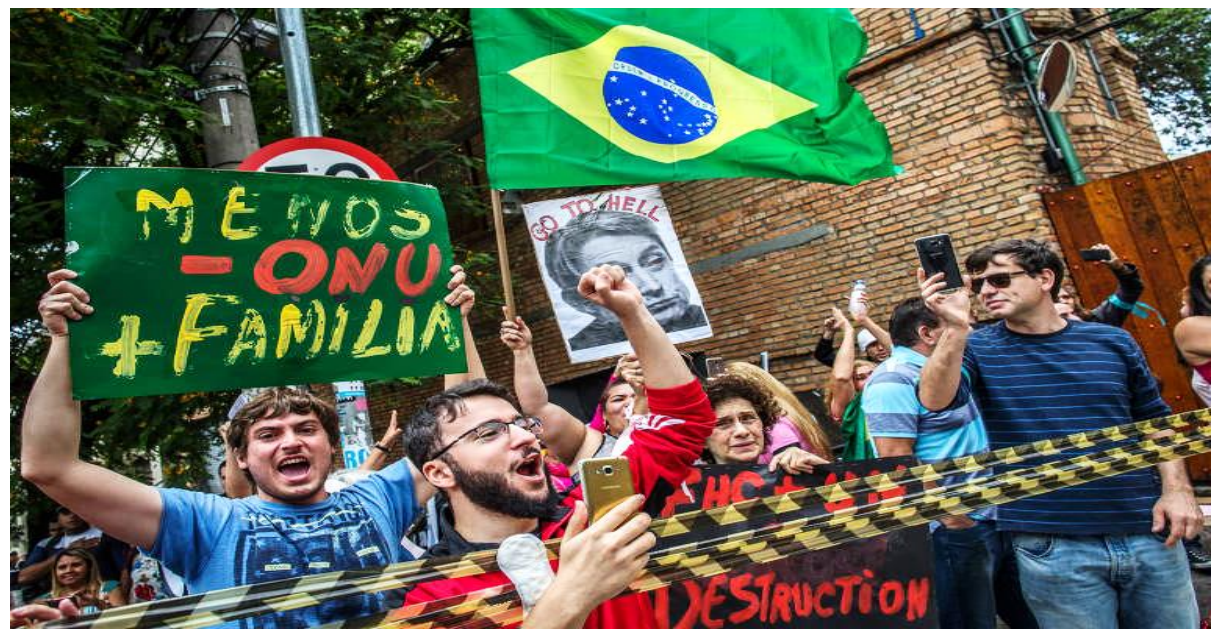

Figura 2: Protesto contra a presença de Judith Butler em São Paulo. 07 nov. 2017.

Foto: Bruno Santos/Folhapress. Acesso em 6 mar. 2019.

\section{arasessaneses \\ Lobby conservador retira igualdade de gênero do Plano Nacional de Educação}

Deputados-pastores impõem derrota em comissão da Câmara à corrente que gostaria de enfatizar superação da homofobia e das desigualdades entre homens e mulheres.

Votação será concluída nesta quarta

por Sarah Fernandes, da RBA | publicado 22/04/2014 19h49

Figura 3: Manchete sobre a pressão conservadora em relação ao Plano Nacional de Educação.

Fonte: Rede Brasil Atual. Acesso em 3 mar. 2019. 
Estes três eventos são indícios do fortalecimento recente do conservadorismo não só no Brasil como em diversos países do mundo. Trata-se de um movimento internacional, intensamente articulado, que vem contribuindo fortemente para a erosão das democracias ou, pelo menos, da laicidade nas democracias ocidentais. Este artigo analisa, a partir de uma perspectiva pós-estrutural, o cenário de retrocesso atual (CARREIRA \& GONÇALVES, 2018; ONU Mulheres, 2016) - marcado por crescentes manifestações de discursos de ódio sexistas, classistas, racistas, generificados e lgbtfóbicos - como sendo também uma reação, como efeito de políticas públicas e governamentais ${ }^{4}$. De alguma forma, tais políticas fizeram com que pessoas e grupos que, ao longo da história do Brasil, sempre tiveram privilégios sociais, se sentissem ameaçados.

Os ataques conservadores têm se constituído como "um conjunto de ações que, de forma crescente, vem cerceando as escolas, a produção científica de pesquisadores/as e grupos de pesquisa, assim como os movimentos sociais e ações artísticas e políticas” (CÉSAR \& DUARTE, 2017, p. 143). A intensificação desses ataques é entendida aqui e em outros textos nossos (MACEDO, 2016; CRUZ, 2019) como uma reação às conquistas de grupos sociais historicamente marginalizados nas sociedades ocidentais.

Um exemplo icônico das políticas sob ataque de grupos (ultra)conservadores no campo da educação formal é o Programa Brasil Sem Homofobia. Criado em 2004, ele possibilitou a criação de programas como o Escola Sem Homofobia - enredado nas polêmicas do chamado "kit gay"5 - e o Projeto Educação para Promoção do Reconhecimento da Diversidade Sexual e Enfrentamento ao Sexismo e a Homofobia. Deste último fazem parte os cursos Gênero e Diversidade na Escola - Formação de Professoras/es em Gênero, Sexualidade, Orientação Sexual e Relações Étnico-Raciais (GDE) $)^{6}$; Gestão de Políticas Públicas em Gênero e Raça (GPP-GeR) ${ }^{7}$ e Gênero e Diversidade Sexual (GDS).

\footnotetext{
${ }^{4}$ Não consideramos que tais políticas foram as únicas responsáveis tanto por atacar as desigualdades sociais no país quanto a gerar as referidas reações (ultra)conservadoras. As atuações das organizações não governamentais, dos movimentos sociais identitários, das produções acadêmicas, dos diversos artefatos da indústria cultural (filmes, peças teatrais, novelas, propagandas, séries, revistas...), postagens nas redes sociais entre outros agentes também contribuíram nesses embates políticos.

${ }^{5}$ Para mais informações, ver Cruz, 2014.

${ }^{6}$ Institucionalmente, o GDE foi elaborado conjuntamente pela Secretaria Especial de Políticas para Mulheres da Presidência da República (SPM/PR), pela Secretaria Especial de Políticas de Promoção da Igualdade Racial da Presidência da República (SEPPIR/PR), pelo Ministério da Educação (MEC), pelo Centro Latino-Americano em Sexualidade e Direitos Humanos do Instituto de Medicina Social da Universidade do Estado do Rio de Janeiro (CLAM/IMS/UERJ) e pelo British Council.

${ }^{7}$ Cabe ressaltar que esse curso e seu material didático também foram elaborados pelo CLAM/IMS/UERJ em 2010, em parceria com SPM, SEPPIR, MEC, Instituto de Pesquisa Econômica Aplicada (Ipea) e Fundo
} 
A utilização multiforme do significante flutuante (LACLAU, 2011) "ideologia de gênero" no Brasil e no mundo por grande parte dos grupos conservadores que o criaram pode ser visto como um exemplo dessa reação. Essa estratégia conservadora é utilizada para combater desde uma hipotética "ameaça comunista" iminente até a destruição da família tradicional ou mesmo da espécie humana, apontando assim para a existência de uma articulação de uma diversidade de demandas que transformaram a "ideologia de gênero" em ponto nodal para a constituição de uma hegemonia conservadora.

Diferentes pesquisadores/as das mais diversas áreas do conhecimento (PARAÍSO, 2018; CORRÊA, 2017; 2018; LOWENKRON \& MORA, 2017, CÉSAR \& DUARTE, 2017; MACEDO, 2018) vêm se debruçando na análise dessa estratégia conservadora que tem conseguido alguns êxitos na obstacularização da efetivação dos Direitos Humanos para uma grande parcela da população historicamente marginalizada. Sonia Corrêa (2017), por exemplo, aponta essa movimentação conservadora como uma "cruzada". Assim como as cruzadas medievais, a atual também foi gestada no seio da Igreja Católica e não tem apenas viés religioso. A autora aponta que o surgimento de tal estratégia ocorreu nos anos 1990, quando surgiram dois marcos internacionais importantes nas disputas sobre as questões de gênero e dos direitos reprodutivos no âmbito internacional: a Conferência sobre População e Desenvolvimento (Cairo, 1994) e a IV Conferência Mundial das Mulheres a ser realizada em Pequim (China, 1995). Mais conhecida como "Conferência do Cairo", a primeira foi pioneira em utilizar o conceito de gênero em um documento oficial internacional, que foi assinado por centenas de países. Corrêa (2017) aponta ainda que no mesmo ano, durante as preparações para a IV Conferência Mundial das Mulheres, a direita católica dos Estados Unidos atacou o conceito de gênero por considerá-lo com "forte potencial desestabilizador da dita ordem natural dos sexos" (CORRÊA, 2017). Rogério Junqueira, em entrevista concedida a Laura Lowenkron e Claudia Mora no Centro LatinoAmericano em Sexualidades e Direitos Humanos (CLAM), corrobora a interpretação de Sonia Corrêa ao apontar que a expressão "ideologia de gênero" foi uma "invenção católica que emergiu sob os desígnios do Conselho Pontifício para a Família, da Congregação para

de Desenvolvimento das Nações Unidas para a Mulher (Unifem). Diferente do GDE, que era voltado para docentes do Ensino Fundamental, o GPP-GER era "direcionado a servidores/as nos três níveis da Administração Pública, preferencialmente gestores/as das áreas de políticas para mulher, relações étnicoraciais, educação, saúde, trabalho, segurança e planejamento, integrantes dos conselhos de Direitos da Mulher, fóruns intergovernamentais de Promoção da Igualdade Racial, conselhos de Educação e dirigentes de organismos da sociedade civil ligados à temática de gênero e de igualdade étnico-racial" (HEILBORN et aliae, 2010, p. 9). 
a Doutrina da Fé", constituída por uma "retórica reacionária antifeminista, sintonizada com o pensamento e o catecismo de Karol Wojtyla" (LOWENKRON \& MORA, 2017), o Papa João Paulo II. O pesquisador aponta ainda que, durante o papado de João Paulo II e com a colaboração de Joseph Ratzinger ${ }^{8}$, foi criada a "Teologia do Corpo", em que se naturalizam traços e comportamentos histórica e socialmente associados às mulheres ${ }^{9}$. Assim, o pontificado de João Paulo II, segundo o autor, radicalizou na defesa de uma moralidade sexual conservadora atacando tudo que era associado à modernidade, como as práticas do aborto, a homossexualidade e as contracepções (LOWENKRON \& MORA, 2017). Rogério Junqueira costura a criação de tal Teologia do Corpo com a gênese da utilização da expressão "ideologia de gênero" afirmando que

Wojtyla, ao fazer da heterossexualidade e da família heterossexual o
centro de sua "antropologia" e de sua doutrina, acabou por produzir uma
teologia cujos postulados situam a heterossexualidade na origem da
sociedade e definem a complementaridade heterossexual no casamento
como fundamento da harmonia social. Deste modo, a Teologia do Corpo
mostrava-se sumamente estratégica para municiar o enfrentamento das
propostas avançadas a partir da Conferência Internacional sobre
População, no Cairo (de 1994), e da Conferência Mundial sobre as
Mulheres, em Pequim (de 1995). Dentre essas propostas, aquilo que viria
a ser mais tarde denominado "ideologia de gênero" seria, segundo a visão
vaticana, um dos mais desventurosos legados (LOWENKRON \&
MORA, 2017).

No entanto, esse legado não foi utilizado no campo religioso apenas pelo catolicismo, tendo a adesão de grupos "evangélicos, mulçumanos, budistas e, no Brasil, espíritas" (CORRÊA, 2017) ${ }^{10}$. Junqueira, nessa mesma entrevista, chama a atenção de que, no Brasil e na América Latina, as igrejas evangélicas neopentecostais não só aderiram a esse legado como se apropriaram dessa retórica antigênero. $\mathrm{O}$ pesquisador também aponta para a atuação de outros atores além dos muros do Vaticano: "além dos dicastérios da Cúria Romana, foram mobilizadas figuras ultraconservadoras de conferências episcopais de diversos países, movimentos pró-vida, pró-família, associações de terapias reparativas (de "cura gay") e think tanks ${ }^{11}$ de direita" (LOWENKRON \& MORA, 2017). Seguindo o

\footnotetext{
${ }^{8}$ Após a morte de João Paulo II, em 2005, Joseph Ratzinger foi eleito seu sucessor em um conclave, passando a ser chamado de Papa Bento XVI. Em 28 de fevereiro de 2013, renunciou ao papado alegando falta de condições de saúde devido à sua idade avançada.

${ }^{9}$ Para aprofundamento sobre essas questões teológicas, ler os seguintes documentos católicos: Homem e Mulher o Criou, de 1984, e Carta às Famílias Gratissimam Sane, de 1994.

${ }^{10}$ A pesquisadora faz uma ressalva que consideramos importante quando lembra que nem todas as pessoas adeptas dessas religiões comungam dessa agenda antigênero.

${ }^{11}$ Termo utilizado para se referir às instituições ou organizações dedicadas a produzir e difundir conhecimento sobre temas políticos, econômicos ou científicos.
} 
rastro de importantes contribuições para a criação e difusão dessa agenda antigênero ${ }^{12}$, o pesquisador destaca a participação da jornalista norte-americana Dayle O'Leary. Ela é ligada à Opus Dei, representante do "lobby católico Family Research Council e da National Association for Research \& Therapy of Homosexuality ${ }^{13}$ (que promove terapias reparadoras da homossexualidade)" (LOWENKRON \& MORA, 2017), possuindo inclusive ligações diretas com a Santa Sé. A jornalista é autora do livro The gender agenda (A agenda de gênero), publicado em 1997, traduzido para diversas línguas ${ }^{14}$ e que foi se transformando em "umas das bíblias do movimento antigênero" (LOWENKRON \& MORA, 2017).

Corrêa (2017) chama a atenção ainda para que, a partir dos anos 2000, o próprio Vaticano auxilia no aumento da produção textual da agenda antigênero quando publica em 2003 o Lexicon dos Termos sobre a Família e, em 2004, a Carta sobre a Colaboração do Homem e da Mulher no Mundo. Mas, assim como as cruzadas medievais tinham objetivos outros que o de libertar a Terra Santa do domínio mouro - como, por exemplo, interesses geopolíticos e econômicos -, a atual cruzada não conta com o apoio apenas de segmentos religiosos ou da direita. Corrêa (2017) aponta também para a participação de membros da comunidade científica e de políticos integrantes da esquerda. É o caso do ex-presidente do Equador Rafael Correa ${ }^{15}$, que, em um de seus programas na TV equatoriana, atacou a “ideologia de gênero que destrói a família” (CORRÊA, 2017).

Ao apresentar um mapeamento do recrudescimento do conservadorismo na América Latina durante o Seminário Internacional Gênero Ameaça(n)do, realizado na Universidade do Estado do Rio de Janeiro no dia 28 de fevereiro de 2019, Sônia Corrêa defendeu que houve um momento de erupção dessas posturas abertamente conservadoras

\footnotetext{
${ }^{12}$ Junqueira aponta para as importantes contribuições do "monsenhor francês Tony Anatrella, da teóloga alemã Jutta Burgraff, da jornalista estadunidense Marguerite Peeters, da escritora alemã Gabriele Kuby, do cardeal guineense Robert Sarah e, claro, do alemão Joseph Ratzinger (...), do ultraconservador cardeal colombiano Alfonso Lopez Trujillo (...), do monsenhor Michel Schooyans" (LOWENKRON \& MORA, 2017).

13 "Conselho de Pesquisa da Família" e "Associação Nacional de Pesquisa e Terapia da Homossexualidade", respectivamente, em tradução livre.

${ }^{14}$ No Brasil, a editora católica Canção Nova editou o livro 10 anos depois de seu lançamento, logo após a visita do Papa Bento XVI ao país, em 2007.

${ }^{15}$ Rafael Correa, juntamente com outros/as mandatários/as da América do Sul (Lula e Dilma no Brasil, Evo Morales na Bolívia, Hugo Chávez na Venezuela, Nestor e Cristina Kirchner na Argentina, Michelle Bachelet no Chile), fazia frente a uma agenda neoliberal e aos interesses dos EUA na região, sendo considerados, portanto - mas não só por isso - como governos de esquerda.
} 
na região, que teria ocorrido entre 2012 e 2014. No Chile, a lei contra discriminação ${ }^{16}$ foi duramente atacada, mas naquele momento ainda não a acusaram de fazer parte da "ideologia de gênero". No Paraguai e no Brasil, os ataques aos planos nacionais de Educação se iniciaram nesse mesmo período; neles se exigia a retirada de qualquer menção às questões de gênero em tais diretrizes educacionais.

Em 2013, uma série de grandes protestos se espalham pelo mundo: as jornadas de junho no Brasil, a Primavera Árabe em diversos países do norte da África, as manifestações contrárias à lei do casamento para todos em Paris ${ }^{17}$, o movimento $15-\mathrm{M}$ na Espanha $^{18}$ (iniciado em 2011) e grandes protestos contra a crise econômica em Portugal, entre outros eventos semelhantes. Algo que une tais eventos, segundo essa pesquisadora, é que um dos principais impactos desses grandes protestos foi a erosão das democracias liberais.

A pesquisadora apontou ainda que o período entre 2016 e 2018 teria sido o ápice desses ataques conservadores, tendo como exemplos os desdobramentos do Acordo de Paz na Colômbia em 2016; em 2017, um ônibus antigênero saiu de Nova York passando por vários países até chegar ao Chile duas semanas antes da votação da lei do aborto naquele país; no final desse mesmo ano os ataques a Judith Butler no Brasil [Figura 2]; os processos eleitorais na Costa Rica e no Brasil em 2018.

Este debate, como estamos vendo, não se restringe ao Brasil nem à América Latina; está presente em pelo menos três continentes: América, Europa e África ${ }^{19}$. No México ${ }^{20}$, em 2017, o ônibus antigênero foi utilizado para barrar "proposições em relação a educação sexual, direitos das pessoas trans, noções de famílias diversas e tentativas de positivar o aborto legal” (CORRÊA, 2017). Na Costa Rica, país onde está sediada o Organização dos

\footnotetext{
${ }^{16}$ Essa lei foi criada no dia 4 de abril de 2012, em um momento de grande comoção nacional pela morte de Daniel Zamudio, de 24 anos, três semanas após ter sido espancado por um grupo de neonazistas. A chamada lei contra a discriminação regulamentou a punição em caso de discriminação por motivos de raça ou etnia, nacionalidade, situação socioeconômica, idioma, ideologia ou orientação política, religião ou credo, participação em organizações gremiais, sexo, orientação sexual, identidade de gênero, estado civil, idade, filiação, aparência pessoal e doença ou incapacidade. Para mais informações, ver: http://g1.globo.com/mundo/noticia/2012/04/chile-aprova-lei-contra-discriminacao-apos-morte-de-jovemgay.html. Acesso em 05 mar. 2019.

${ }^{17}$ Corrêa afirmou nesse evento que tais manifestações em Paris são consideradas um marco das guerras contra o gênero na Europa.

${ }^{18}$ Grandes manifestações organizadas através das redes sociais que exigiam "democracia real já!".

${ }^{19}$ Segundo Junqueira (LOWENKRON \& MORA, 2017), a ofensiva antigênero está presente em 50 países.

${ }^{20}$ No Seminário da UERJ, Corrêa chamou a atenção para que o México é um enigma, pois, apesar da forte presença católica no país, a polêmica sobre a "ideologia de gênero" não foi utilizada até então. No entanto, o recém-empossado presidente de esquerda Andrés Manuel López Obrador tem dados declarações e defendido posições que se aproximam bastante da agenda antigênero.
} 
Estados Americanos (OEA) - portanto, um país simbólico nessas disputas -, a eleição presidencial de 2018 foi fortemente afetada pela estratégia de acionar as polêmicas em relação à "ideologia de gênero" 21 . Tal estratégia foi utilizada pela campanha ultraconservadora do pastor Fabricio Alvarado, que chegou a ir para o segundo turno da eleição presidencial com o candidato governista de centro-esquerda Carlos Alvarado. Durante o segundo turno houve reação principalmente de movimentos feministas. Dezenas de mulheres chegaram a ir votar no segundo turno fantasiadas de "criadas", em referência ao livro $O$ conto da criada (1985), da escritora canadense Margaret Atwood, como forma de protesto contra o autoritarismo religioso naquele país ${ }^{22}$. Ao fim, a candidatura conservadora foi derrotada, alcançado $40 \%$ dos votos.

No Peru, como reação à proposta do Governo Pedro Pablo Kuczynski de introduzir no currículo escolar a perspectiva da igualdade de gênero, lideranças conservadoras criaram no fim de 2016 o movimento CMHNTM (Con mis Hijos no te Metas - Não se meta com meus filhos, em tradução livre) que aparece na primeira imagem deste artigo [Figura 1] marchando na cidade de Trujillo. Esse movimento utiliza como um de seus slogans a expressão "Gênero nunca mais" e alega defender a liberdade sendo "a favor da família e pelo direito dos pais de educar seus filhos", em uma evidente aproximação com as bandeiras do Movimento Escola Sem Partido. O movimento peruano visa fazer, em todos os países do continente, oposição conjunta a qualquer política pública que trate das questões de gênero, já estando presente, além do país onde surgiu, na Argentina, na Colômbia, no Paraguai ${ }^{23}$ e na Bolívia, tendo entrado em contato com parlamentares da bancada da bíblia e com o presidente Jair Bolsonaro em novembro de 2018. No Peru, conseguiram barrar na justiça a política educacional do Governo Pedro Pablo, além de derrubar dois ministros da Educação.

\footnotetext{
${ }^{21}$ Para mais detalhes do caso costarriquenho, mas também do peruano, colombiano e brasileiro, assistir ao documentário Gênero sob ataque produzido pelo Consorcio Latinoamericano contra el Aborto Inseguro (CLACAI) e disponível em: https://www.youtube.com/watch?v=Aj3St_zUM7M\&pbjreload=10. Acesso em 08 mar. 2019.

22 Para mais informações ver: http://elmundoenmarcha.net/internacionales/mujeres-votan-vestidas-decriadas-contra-autoritarismo-religioso-en-costa-rica/. Acesso em 09 mar. 2019.

${ }^{23}$ Essa postura conservadora em relação às questões de gênero nesse país não é recente. No documento final da IV Conferência das Nações Unidas sobre a Mulher, realizada em Pequim em 1995, o Vaticano solicitou reserva em relação ao termo "gênero", utilizado pela primeira vez em um documento oficial internacional, pois considera que o termo se refere apenas a homens e mulheres. O Paraguai, país mais católico da região, desde então acompanha o posicionamento do Vaticano em relação a esse conceito. Além disso, Sonia Corrêa, em sua participação no seminário Gênero Ameaça(n)do de 2019, aponta que esse país desde os anos 1990 tem sido uma espécie de "campo de teste, um laboratório" das estratégias, alianças e disseminação de ideias conservadoras na região.
} 
Corrêa (2017) também aponta que, na Europa, países como Espanha, Itália, Polônia, Áustria, Croácia e França também têm registrado fortes movimentações dos grupos antigênero. Na França, agiram fortemente contrários à votação sobre casamento entre pessoas do mesmo sexo. Em 13 de outubro de 2018, o primeiro-ministro da Hungria, Viktor Orban, assinou um decreto que retirou os estudos de gênero da lista de programas de pós-graduação que já havia sido aprovada pelo governo daquele país. Além disso, cortou todo financiamento público para pesquisas nessa área. Essas medidas foram justificadas pelo governo ultraconservador da Hungria por considerar que esse campo de pesquisa não faz ciência, e, sim, ideologia ${ }^{24}$.

Corrêa (2019) destaca, ainda, que a atuação desses grupos antigênero ocorreram/ocorrem em países fortemente católicos, como Paraguai e Argentina, em países com maior pluralismo religioso, como o Brasil, ou onde o número de fiéis cristãos vem caindo, como é o caso do Chile, ou ainda na França, país de forte tradição laica, não sendo possível, portanto, traçar um perfil religioso comum das sociedades onde tais estratégias vêm sendo colocadas em prática. Esses ataques antigênero ocorrem tanto em governos de esquerda, em que tais estratégias são utilizadas inclusive para atacar os governos, como ocorreu no Brasil, como nos de direita, como no caso da Colômbia. Além disso, a situação se complexifica na região da América Latina, pois governos considerados de esquerda como o do Rafael Correa e agora o atual governo mexicano - defendem as mesmas bandeiras dessa agenda.

Para além do debate estritamente ligado à moralidade sexual/familiar, o significante flutuante "ideologia de gênero" foi utilizado para interferir em acontecimentos/processos dos mais variados. Na África subsaariana utilizam o argumento de que o termo "gender" possui um traço da colonialidade ocidental para combater a difusão da alegada ideologia. Na Colômbia, ainda segundo Corrêa (2017), em 2016, durante as campanhas para o referendo sobre o Acordo de Paz intermediado por Cuba entre o governo nacional colombiano e as Forças Armadas Revolucionárias da Colômbia (FARC), os antigênero, especialmente pastores evangélicos, utilizaram o significante flutuante "ideologia de gênero" para tentar barrar o processo, já que os negociadores teriam relações com Cuba, um país comunista, ou ainda com a religiosidade afro-cubana descrita como sendo constituída por uma adoração ao Diabo.

${ }^{24}$ Para mais informações, ver: http://www.diretodaciencia.com/2018/10/18/governo-da-hungria-proibeestudos-de-genero-em-cursos-superiores/. Acesso em: 8 jan. 2019. 
Os alvos da agenda antigênero são adaptáveis de acordo com cada contexto. Ora miram nas feministas, ora em adeptos de religiões de matriz africana, ora nas pessoas LGBT, depois artistas, estrangeiros/as, mais à frente pesquisadores/as, em um outro momento em partidos de esquerda e qualquer outro grupo identificável como obstruindo ou que venha a dificultar a efetivação/perpetuação de seus interesses. As estratégias indicam forte grau de articulação, pois são sempre muito parecidas: "mobilizam lógicas e imaginários simplistas, esquemáticos (...), alimentando pânicos morais que distraem as sociedades de problemas estruturais que deveriam estar sendo debatidos, como as crescentes desigualdades de gênero, mas também de classe, raça e etnia" (CORRÊA, 2017). Junqueira (LOWENKRON \& MORA, 2017) vai na mesma direção ao apontar para a tática da ridicularização e estigmatização dos adversários para não só disseminar mais rapidamente o pânico moral como para angariar apoio. Dessa forma, grupos e pessoas apontados como adversários são nomeados como "destruidores da família, familiofóbicos, homossexualistas, gayzistas, feminazis, pedófilos, heterofóbicos, cristofóbicos" (LOWENKRON \& MORA, 2017). O campo científico não fica de fora desses embates, já que

as formulações teóricas dos adversários devem ser capturadas, descontextualizadas, homogeneizadas, esvaziadas, reduzidas a uma teoria, distorcidas, caricaturadas e embutidas de elementos grotescos para serem, finalmente, denunciadas e repelidas. O seu público-alvo, os atores cujas mentes e corações eles anseiam alcançar, seduzir e arrancar adesão, são principalmente gestores públicos, parlamentares, juristas, jornalistas, dirigentes escolares, eleitores (LOWENKRON \& MORA, 2017).

Ainda segundo o pesquisador, essas articulações e estratégias também visam fazer com que as igrejas voltem a ser um ator político importante na vida social de países mais secularizados ou manter sua influência em sociedades que estão passando por avanços seculares atualmente, principalmente as que têm feito esforços para garantir a efetivação dos Direitos Humanos de minorias (LOWENKRON \& MORA, 2017).

Corrêa (2019) aponta ainda que o modus operandi desses movimentos combina dois tipos de atuação: um com ações contínuas e outro com ações bombásticas. As ações contínuas seriam as obstacularizações constantes a toda iniciativa que envolva educação sexual e questões de gênero nas escolas ou discussões sobre a legalização do aborto. Os atos bombásticos são realizados durante processos eleitorais ou produzidos em eventos específicos, como as manifestações do movimento CMHNSM em diversos países da 
América do Sul e os ataques a Judith Butler em São Paulo (um deles ${ }^{25}$ retratado na Figura 2 deste artigo).

Não à toa, esse ataque bombástico é realizado tendo como alvo a autora justamente por suas ideias constituírem-se como um dos pilares de uma filosofia da diferença contemporânea, que afirma a radicalidade do reconhecimento da alteridade como ética voltada para o combate à vulnerabilidade social de determinados grupos, ou seja, agir para que toda e qualquer vida humana seja "digna, mais vivível, de maneira que esta já não se veja afetada por formas de precariedade impostas ${ }^{26 "}$ (BUTLER, 2017, p. 18). É exatamente esse tipo de debate e de ética que tais grupos conservadores pretendem extirpar da cena pública.

Se na pauta moral os setores religiosos conservadores tentam minar a discussão de temas como legalização do aborto, casamento entre pessoas do mesmo sexo, políticas educacionais que tratem da constituição das diferenças - sobretudo as ligadas ao gênero e às sexualidades -, a adoção por parte de casais não heteronormativos etc., há também estreitamento no campo socioeconômico com setores que defendem o neoliberalismo. Assim, além de defenderem a dita "família natural", a "família tradicional", também têm defendido uma "cultura de performatividade competitiva" (BALL, 2004), uma desregulamentação da economia por parte do Estado, aludindo, entre outras coisas, à privatização do espaço e de empresas públicas, à diminuição ou mesmo à extinção de qualquer tipo de assistência social pública, atingindo em cheio as parcelas da população que são postas em situação mais vulnerável, em que a perda dessas vidas dificilmente são vistas pelos setores neoliberais como dignas de choro (BUTLER, 2017). Dessa forma, após a utilização mais que maleável do "slogan ideologia de gênero" (PARAÍSO, 2018), outro slogan vem sendo utilizado: "Mais família, menos Estado" (LOWENKRON \& MORA, 2017). Nesse contexto, a família que se quer que aumente é a dita “família natural”, ou seja, a constituída por um casal heterossexual, monogâmico e de preferência cristão, significação evidentemente marcada por traços religiosos, mas que se pretende substancializado, universalizado. Na medida em que a precarização social aumenta na mesma proporção em que o Estado se ausenta das responsabilidades de garantir os direitos sociais, tal precarização da vida passa a ser vista por essa ótica neoliberal como sendo da

\footnotetext{
25 Além desse ocorrido em frente ao SESC Pompéia, Butler também enfrentou protestos no Aeroporto Internacional de Guarulhos.

${ }^{26}$ Tradução livre realizada por nós a partir do texto em espanhol.
} 
alçada individual e/ou familiar. No caso familiar, é justamente sobre as mulheres, principalmente as negras e pobres, que tais problemas recaem, já que tradicionalmente são vistas como responsáveis pelo bem-estar de todos os membros da família na alçada doméstica.

Vargas (2003), ao tratar a relação entre neoliberalismo e gênero, aponta que o custo social dos ajustes e reformas econômicas da agenda neoliberal acaba recaindo principalmente sobre as mulheres, e ainda mais sobre as pobres e negras. Assim, se não há mais creches públicas ou condições para pagar por uma instituição privada (ou as taxas das públicas que um dia foram gratuitas), caberia a elas zelar pelas crianças fazendo com que muitas ou abandonem o emprego, criando ou fortalecendo a dependência econômica do marido (e/ou outras pessoas com quem convivem) ou possuindo jornadas de trabalho duplas ou triplas dentro e fora de casa. Ou seja, são justamente as questões de gênero que a agenda conservadora quer impedir que se debatam, seja no âmbito familiar, seja no âmbito público.

Baggio (2016) e Macedo (2017; 2018) analisam como os interesses da Atlas Network, uma organização internacional ultraliberal, estão imbricados na intensificação de tais polêmicas e na produção e sedimentação de uma racionalidade neoliberal. Essa organização, cujo presidente é ligado à Opus Dei da Igreja Católica, está presente em mais de 90 países por meio de aproximadamente 470 organizações, tendo entre seus financiadores "a família Koch, magnatas do ramo do petróleo e ativistas políticos americanos vinculados a alas radicais do partido republicano" (MACEDO, 2018, p. 8). No Brasil, a Rede Atlas está presente em pelo menos 15 organizações: Instituto Ludwig Von Mises Brasil; Instituto Millenium; Instituto Liberdade; Instituto Liberal de São Paulo e Rio de Janeiro; Estudantes para a Liberdade (Students for Liberty) São Paulo; Centro Mackenzie de Liberdade Econômica; Livres; Líderes do Amanhã; Instituto de Formação de Líderes de São Paulo, Belo Horizonte e Santa Catarina; Instituto de Estudos Empresariais; Instituto Atlantos.

É em meio a esses embates e articulações internacionais que a disputa por uma nova governamentalidade (CÉSAR \& DUARTE, 2017) na área educacional se tornou um dos alvos preferenciais dessas agendas antigênero e neoliberal que acusam as escolas de serem espaços de doutrinação contra os valores tradicionais, contra uma suposta ordem natural das coisas, seja no campo moral, seja no campo econômico. A fragilidade dessa norma que defende uma suposta ordem natural das coisas é tanta que é preciso um pesado 
investimento cotidiano, familiar, educacional, religioso, médico, jurídico que a reitere constantemente para que ela siga existindo. Além disso é preciso que não ocorram a problematização e a historicização de significantes como "natural", "normal", "universal" tão utilizados nesses embates por todos os lados do conflito, pois quanto mais sutil esses processos arbitrários se derem, mais eficazes serão seus efeitos de substancialização e naturalização (BUTLER, 2008).

Assim, como apontam Maria Rita César e André Duarte (2017), nesta guerra político-moral "o gênero, a sexualidade e a diversidade sexual foram transformados em armas" (p. 144). No campo educacional brasileiro, em que políticas, programas e legislações apontam e justificam abordagens de questões que envolvem a diferença não só em relação ao gênero, mas também às sexualidades, às raças, às etnias etc., a escola é vista por essas alas conservadoras como um lugar que tem se transformado em ameaçador e, por isso, seria preciso "defender as crianças" desses ataques. Oliveira (2013), ao analisar essa estratégia de utilizar os interesses das crianças para manter práticas que sedimentam as desigualdades sociais, afirma que a figura da criança "sempre é usada como um objeto fantasmagórico, mas também um lócus de ventriloquismo social, em que, através dessa criança que nunca pode chegar a falar, vários movimentos e pessoas conservadoras a usem para impor a heteronormatividade como única possibilidade" (OLIVEIRA, 2013, p. 72).

Assim, o dispositivo da infância e da defesa da família - como exemplifica uma das fotos na introdução deste capítulo [Figura 2] - é utilizado aqui como mais uma forma de angariar apoio contra tais práticas escolares que visam combater discriminações, exclusões e desigualdades sociais arraigadas na cultura brasileira. Além disso, esses grupos jogam o tempo todo com a tática da inversão. Ao defenderem a censura à livre manifestação do pensamento científico e artístico e ao livre exercício da profissão docente, afirmam estar defendendo a liberdade de expressão e de crença das famílias. No Brasil, o Movimento Escola Sem Partido encampou esse discurso e é um dos mais ativos e visíveis atores dessas disputas entre dois dispositivos de governamento biopolítico opostos (CÉSAR \& DUARTE, 2017), em que o conservadorismo vem anulando diversas conquistas que procuravam garantir uma democracia mais radical mediante a criação de uma cultura de respeito aos Direitos Humanos.

No caso brasileiro, Corrêa (2018), em um ensaio preliminar logo após a vitória de Jair Bolsonaro, aponta dimensões e processos que devem ser levados em conta para entender como um candidato com um discurso abertamente antidemocrático e autoritário 
conseguiu se eleger em uma das maiores democracias do planeta, aprofundando assim o processo de de(s)mocratização. Segundo ela, a permanência tanto das desigualdades quanto de uma violência estrutural sem solução mesmo após 30 anos da redemocratização; a cultura de uma corrupção política enraizada; o crescimento e sedimentação de um dogmatismo moral religioso principalmente evangélico, mas também de uma restauração conservadora católica após anos 1980; as baixas taxas de crescimento econômico desde os anos de 1980 e a devastação das taxas de emprego da parcela mais pobre da população com a recessão de 2015 e que teria levado grandes parcelas da classe média mais à direita; a frustração de parcela da população com os casos de corrupção no Partido dos Trabalhadores; a propaganda partidária-midiática antipetista; e a campanha cibernética de Bolsonaro via principalmente WhatsApp são alguns fatores que nos ajudariam a entender o que se passou/passa neste país. Corrêa (2018) afirma ainda que a guinada da política brasileira para a direita só pode ser compreendida se levarmos em conta as "transformações que tiveram lugar nas ordens de gênero e sexualidade no decorrer da reconstrução democrática e na contramão das camadas entrincheiradas de desigualdade e conservadorismo que (...) devem ser pensadas em suas interseções com o racismo" (p. 4-5).

Assim como nós em outros trabalhos (CRUZ, 2019; MACEDO, 2018), Corrêa (2018) também interpreta a ebulição política ocorrida no Brasil a partir de 2013 como uma reação conservadora às transformações sociais que vinham ocorrendo no país no sentido de fortalecer uma democracia sexual e sedimentar uma cultura de valorização dos Direitos Humanos em que as políticas igualitárias ${ }^{27}$, em especial as políticas educacionais, tiveram grande participação. No entanto, é preciso olhar também para o retrato geopolítico internacional atual. Como foi apontado em relação ao uso estratégico da polêmica sobre a "ideologia de gênero", há uma movimentação internacional conservadora antidemocrática. Logo após a vitória de Donald Trump nos EUA em 2016, a instituição SPW (Sexuality Policy Watch) lançou uma nota ${ }^{28}$ afirmando que, longe de ser uma excepcionalidade, tal vitória se inseria em uma cadeia de transformações antidemocráticas globais que se teria iniciado com a "guerra ao terror" promovida pelo governo norte-americano após os atentados de 11 de setembro de 2001. De acordo com Corrêa (2018), tal evento pode ser visto como uma ruptura do processo de democratização iniciado nos anos 1970 e que

\footnotetext{
${ }^{27}$ De acordo com Daniela Auad (2008), "políticas de educação para a igualdade de gênero" (p. 52).

${ }^{28}$ A SPW é um fórum global formado por pesquisadores/as e militantes. Para ler a referida nota na íntegra, ver: https://sxpolitics.org/spw-view-on-trumps-victory/16132. Acesso em: 09 mar. 2019.
} 
parecia irreversível após o fim da Guerra Fria. Essa ruptura, segundo a autora, também teria ocorrido naquele período em outras regiões do planeta, como a tentativa fracassada de um golpe de Estado na Venezuela que tentou derrubar o então presidente Hugo Chávez em $2002^{29}$ e a chagada ao poder de Putin na Rússia e de Erdogan na Turquia. Golpes de Estado foram efetivados nos anos seguintes na América Latina, como o de Honduras (2009) e no Paraguai (2012), apontando para o recrudescimento do processo de de(s)mocratização.

Luciana Ballestrin (2017) chama a atenção para o fato de que em 2016, além da eleição de Trump nos EUA, pelo menos outros três "eventos foram capazes de questionar os limites da democracia representativa, liberal e ocidental" (p. 2): o plebiscito que decidiu pela saída do Reino Unido da União Europeia, a rejeição do referendo pelo Acordo de Paz com as Forças Revolucionárias da Colômbia (FARC) e a destituição da presidenta Dilma Rousseff. Segundo Ballestrin (2017), esses quatro eventos conectam os seguintes fenômenos ocorridos nas mais diversas partes do planeta: "a emergência de discursos abertamente autoritários, anti-humanistas e antidemocráticos; sua eventual legitimação pelo voto popular, partidos políticos e/ou lideranças populistas; e a utilização das instituições democráticas para a fragilização, minimização ou ruptura da própria democracia" (BALLESTRIN, 2017, p. 2). O Brasil, ao consolidar o impeachment da presidenta Dilma Rousseff em 2016, passou a ser entendido como exemplo de um caso pós-democrático $^{30}$ (SINTOMER, 2017) ou de um processo de desdemocratização ${ }^{31}$ (DARDOT \& LAVAL, 2016) para pesquisadores/as do campo da Ciência Política.

Dessa forma, o acordo de paz na Colômbia, as eleições de 2018 na Costa Rica e no Brasil podem ser classificadas como o que Fernando Serrano-Amaya (2017) denomina "tormentas perfeitas", ou seja, quando um conjunto de forças e condições facilita a agregação de público e questões bastante diversas. Segundo Corrêa (2019), tais tormentas perfeitas possuem efeitos de grande escala tanto nas macropolíticas nacionais (derrota do

\footnotetext{
${ }^{29}$ Com ativa participação do Governo Bush, a tentativa de golpe contou também com a participação dos grandes meios de comunicação, do grande empresariado nacional e da cúpula das forças armadas venezuelanas. O documentário A revolução não será televisionada, filmado e dirigido pelos irlandeses Kim Bartley e Donnacha O'Brian, aborda em profundidade tais acontecimentos. Disponível em: https://www.youtube.com/watch?v=R-7c34tYH1c. Acesso em 9 mar. 2019.

${ }^{30}$ Segundo Sintomer (2017), a pós-democracia "é um sistema em que, na aparência, nada muda em relação à democracia ocidental clássica: seguem organizando eleições livres, o Poder Judiciário é independente, os direitos individuais são respeitados. A fachada é a mesma, mas o poder real está em outra parte. As decisões são tomadas pelas direções das grandes corporações transnacionais, os mercados, as agências de qualificação, as organizações internacionais e os organismos tecnocráticos" (p. 31-32). Tradução feita por nós.

${ }^{31}$ Esvazia-se substancialmente a democracia sem extingui-la formalmente (DARDOT \& LAVAL, 2016).
} 
referendo sobre o acordo da paz na Colômbia; a quase eleição de um pastor ultraconservador na Costa Rica e a eleição de Jair Bolsonaro para presidente do Brasil) quanto na dimensão geopolítica (nomeação do ex-procurador ultraconservador Alejandro Ordóñez $^{32}$ como embaixador da Colômbia na Organização dos Estados Americanos; nomeação do atual ministro das Relações Exteriores, o chanceler Ernesto Araújo, e o discurso da ministra Damares Alves no Conselho de Direitos Humanos da Organização das Nações Unidas, em que defendeu o direito à vida desde a concepção, em evidente obstacularização das discussões sobre a legalização do aborto).

No Brasil, as movimentações de Bolsonaro apontam para um aprofundamento do processo de de(s)mocratização. Recentemente, em entrevista ao pastor Silas Daniel ${ }^{33}$, o então presidente eleito Jair Bolsonaro (PSL-RJ) afirmou que, apesar de o Estado brasileiro ser laico, ele tomará decisões no governo de acordo com valores cristãos. Ele reforçou ainda a intenção de acabar com o que ele denomina "ideologia de gênero nas escolas":

O Estado é laico, mas eu sou cristão. Eu não vou negar isso aí. Muita coisa vai ser votada de acordo com meus princípios, valores. A questão, por exemplo, de ideologia de gênero. A gente vai acabar com essa história lá via Ministério da Educação. Escola é lugar de criança ser instruída, e não ser doutrinada ou estimulada precocemente para o sexo. Quem ensina sexo é papai e mamãe (G1, 29 dez. 2018).

Em seu discurso no Congresso Nacional durante a posse presidencial, no dia $1^{\circ}$ de janeiro de 2019, em Brasília, o presidente Jair Bolsonaro (PSL) mais uma vez atacou o que ele e sua base política consideram "ideologia de gênero" e "doutrinação nas escolas", ao afirmar que no governo que se inicia irão

unir o povo, valorizar a família, respeitar as religiões e nossa tradição judaico-cristã, combater a ideologia de gênero, conservando nossos valores. O Brasil voltará a ser um país livre das amarras ideológicas. (...) Daqui em diante, nos pautaremos pela vontade soberana daqueles brasileiros que querem boas escolas, capazes de preparar seus filhos para o mercado de trabalho e não para a militância política (Folha de S. Paulo, 1 jan. 2019) $)^{34}$.

\footnotetext{
${ }^{32}$ Pensador da ideologia de gênero na América Latina.

33 A entrevista foi realizada em 11 de dezembro de 2018, no entanto a só foi divulgada no Twitter do presidente eleito no dia 29 de dezembro de 2018. Disponível em: https://g1.globo.com/politica/noticia/2018/12/29/bolsonaro-relata-ameaca-de-boicote-ao-brasil-e-diz-queainda-avalia-se-vai-mudar-embaixada-para-jerusalem.ghtml. Acesso em 29 dez. 2018.

34 A íntegra do discurso de posse está disponível em: https://www1.folha.uol.com.br/poder/2019/01/leia-aintegra-do-discurso-de-bolsonaro-na-cerimonia-de-posse-no-congresso.shtml. Acesso em 7 jan. 2019.
} 
Ao afirmar que o papel da escola não será mais de formar alunos/as para a militância política, o presidente se coloca ao lado do Movimento Escola Sem Partido, em uma "posição pós-política" (BALL, 2001), apresentada como pragmática e possuindo uma suposta neutralidade ideológica, tema já discutido e superado no meio acadêmicopedagógico há pelo menos 30 anos.

Ainda no dia da posse, o presidente assinou uma medida provisória que transferiu a atribuição de identificar, delimitar e demarcar terras indígenas e quilombolas para o Ministério da Agricultura ${ }^{35}$, chefiado pela líder da bancada ruralista Tereza Cristina ${ }^{36}$ (DEM-MS). No segundo dia de seu governo, foram confirmadas as extinções do Ministério da Cultura e do Ministério do Trabalho, além da Secadi ${ }^{37}$, a secretaria do Ministério da Educação responsável por trabalhar com o tema da diversidade na educação brasileira e que visava combater os preconceitos e discriminações nesse âmbito referentes aos mais diversos marcadores sociais da diferença.

Ainda no dia 2 de janeiro, circulou pelas redes sociais um vídeo da ministra da Mulher, Família e Direitos Humanos - ministério que agora engloba o que no período do Governo Lula eram a SDH, SPM e SEPPIR -, a advogada e pastora Damares Alves, em que ela efusivamente afirma que "é uma nova era no Brasil: menino veste azul e menina veste rosa" ${ }^{38}$. No mesmo dia, personalidades do mundo artístico e político rebateram essa declaração postando nas redes sociais fotos e vídeos vestindo roupas com as cores contrárias ao que a ministra defendeu em sua declaração. Damares, na solenidade de transmissão de cargo, ao assumir a chefia do referido ministério, fez outra declaração em sintonia com as afirmações do presidente Bolsonaro: “o Estado é laico, mas esta ministra é

\footnotetext{
${ }^{35}$ Até então, a demarcação de terras indígenas era função da Fundação Nacional do Índio (Funai), vinculada ao Ministério da Justiça. Já o tema das terras quilombolas era função do Instituto de Colonização e Reforma Agrária (Incra), vinculado à Casa Civil. Durante sua campanha presidencial, Bolsonaro defendeu titularizar as terras indígenas para permitir a exploração comercial e a venda dessas terras. Para mais informações, acessar: https://g1.globo.com/politica/noticia/2019/01/02/bolsonaro-transfere-para-aagricultura-as-atribuicoes-sobre-demarcacao-de-terras-indigenas-e-quilombolas.ghtml. Acesso em 7 jan. 2019.

${ }^{36}$ Segundo a jornalista Cristiane Sampaio, a ministra é conhecida nos bastidores como "musa do veneno", por ser uma das principais defensoras do Projeto de Lei $\mathrm{n}^{\circ}$ 6.299/02, apelidado de "PL do veneno" por flexibilizar as regras para o uso de agrotóxicos. A ministra já declarou que, em sua gestão, os agrotóxicos terão "muito espaço". Para mais detalhes ver: https://www.brasildefato.com.br/2018/11/09/musa-doveneno-saiba-quem-e-a-ministra-da-agricultura-de-bolsonaro/. Acesso em 7 jan. 2019.

37 Para mais detalhes ver: https://www1.folha.uol.com.br/educacao/2019/01/velez-desmonta-secretaria-dediversidade-e-cria-nova-subpasta-de-alfabetizacao.shtml. Acesso em 3 jan. 2019.

38 Para ver o vídeo e ter mais informações a respeito de episódio, acessar: https://g1.globo.com/politica/noticia/2019/01/03/em-video-damares-alves-diz-que-nova-era-comecou-nobrasil-meninos-vestem-azul-e-meninas-vestem-rosa.ghtml. Acesso em 7 jan. 2019.
} 
terrivelmente cristã",39. Ainda nesse evento, a ministra declarou: "neste governo, menina será princesa e menino será príncipe. Ninguém vai nos impedir de chamar meninas de princesas e os meninos de príncipes. Vamos acabar com o abuso da doutrinação ideológica" ${ }^{40}$. Outro integrante do atual governo que tem feito declarações nesse sentido é o ministro da Educação, Ricardo Vélez Rodríguez. Em seu discurso de posse, Rodríguez afirmou que em sua gestão combaterá o que ele chama de "marxismo cultural" e que não permitirá pautas que considera "nocivas" e que vinham sendo "impostas" ao país ${ }^{41}$.

Esses movimentos e as declarações de integrantes do atual governo brasileiro reforçam a ideia de que estaria em curso no Brasil uma "cristianização da educação" $\left(\right.$ MATTOS, 2019) ${ }^{42}$. Amana Mattos, ao analisar as disputas políticas nos textos de projetos de lei e suas implementações, aponta que, apesar de o processo de cristianização da educação ocorrer em paralelo ao Movimento Escola sem Partido, ambos possuem estreita ligação entre seus objetivos e atuações. A pesquisadora informou ainda que, no último dia 22 de fevereiro, uma série de projetos de lei (PL) que intensificam tal cristianização foram desarquivados no Congresso Nacional. Entre esses projetos estão o PL no 943/15, de autoria do deputado federal Alfredo Kaefer (PSDB-PR), que propõe alterar a Lei ${ }^{\circ} 9.394$ (Lei de Diretrizes e Bases da Educação Nacional - LDB) para incluir o "ensino da Bíblia nos ensinos fundamental e médio"43. Já o PL no 9.164/17, de autoria do deputado e excandidato à presidência Cabo Daciolo (Avante-RJ), vai na mesma direção do projeto anterior, mas de forma mais radicalizada, ao propor que se altere a LDB para que o ensino da Bíblia seja inserido nesta legislação educacional como "disciplina obrigatória no currículo do ensino fundamental e médio" ${ }^{44}$. Outro projeto que foi desarquivado naquela data foi o PL $\mathrm{n}^{\mathrm{o}}$ 5.336/16, do deputado federal Jefferson Campos (PSD-SP), que visa

\footnotetext{
${ }^{39}$ Idem.

${ }^{40}$ Para mais informações sobre essa declaração acessar: https://oglobo.globo.com/sociedade/menina-seraprincesa-menino-principe-diz-ministra-da-mulher-familia-direitos-humanos-23341446. Acesso em 7 jan. 2019.

41 Para mais informações sobre as declarações do ministro acessar: https://g1.globo.com/politica/noticia/2019/01/02/ricardo-velez-rodriguez-assume-ministerio-da-educacaoem-cerimonia-em-brasilia.ghtml?fbclid=IwAR0RNcuDt3xtDRDE_vZYL6RtaeDBvM69mkWILW8-inpCRaX7Lo626hbs8U. Acesso em 8 jan. 2019.

42 Tese defendida pela pesquisadora Amana Mattos na mesa Resistências Interdisciplinares do Seminário Gênero Ameaça(n)do, realizado na Universidade do Estado do Rio de Janeiro no dia 28 de fevereiro de 2019.

43 Disponível em: https://www.camara.leg.br/proposicoesWeb/fichadetramitacao?idProposicao=1190656. Acesso em 9 mar. 2019.

44 Disponível em: https://www.camara.leg.br/proposicoesWeb/fichadetramitacao?idProposicao=2163154. Acesso em 9 mar. 2019.
} 
acrescentar o parágrafo 10 no Art. 26 da LDB para “incluir a 'Teoria da Criação' na base curricular do ensino fundamental e médio" ${ }^{\circ 5}$.

\section{CONSIDERAÇÕES FINAIS}

A articulação de uma moral sexual conservadora com uma agenda políticoeconômica neoliberal, como posto acima, visa acelerar uma normatização neoliberal da vida, em que a economia de mercado passa a servir de princípio para a atuação do Estado (FOUCAULT, 2008). Assim, não é o fim do Estado o que se pretende, mas sim que ele deixe de interferir sobre os efeitos excludentes do mercado na sociedade e passe a agir cada vez mais no sentido de governamentalizar a população para submetê-la a uma lógica concorrencial em que cada pessoa passa a ser vista como um “"espaço econômico' onde pode enfrentar os riscos individualmente" (FOUCAULT, 2008, p. 198), já que a rede de proteção social estatal, esta sim, passa a ser eliminada. Ao se disseminar uma ética social empresarial, cada vez mais se fortalece o processo de judicialização dos conflitos sociais. É o que temos acompanhado no campo educacional quando tal ética se alia a uma pauta conservadora dos costumes. Diversos/as professores/as e escolas vêm sendo autuados/as como forma de inibir práticas que visem à democratização do acesso, permanência e do aprendizado de crianças e jovens, mesmo que pela legislação atual tais práticas sejam teoricamente nulas.

Tal nulidade ocorreria porque a Constituição Federal de 1988 garante o livre exercício da profissão, de expressão e, principalmente, em um ambiente educacional, do livre debate de ideias, da livre difusão do conhecimento científico e cultural; essa estratégia de utilizar um discurso jurídico como forma de intimidação, se um por um lado pode realmente inibir a continuidade da abordagem de determinados temas, por outro pode alertar e envolver a comunidade escolar que por ventura esteja fora desse debate. "O que é isso que não querem que eu fale, que eu aborde em sala de aula?" pode ser a deixa para que um maior número de profissionais se interessem por determinada temática, fazendo com que tal estratégia tenha o efeito inverso do pretendido - eliminar essas temáticas e minar uma ética democrática no campo educacional -, apontando para o caráter incontrolável do processo social.

45 Disponível em: https://www.camara.leg.br/proposicoesWeb/fichadetramitacao?idProposicao=2085037. Acesso em 9 mar. 2019. 
Se o campo educacional tem sido um dos alvos preferenciais do entrelaçamento da agenda (ultra)conservadora nos costumes com a agenda (ultra)neoliberal é porque ele ainda tem sido um dos grandes obstáculos nesse processo de construção de uma subjetividade empresarial. Além disso, esse campo tem sido constituído no contexto brasileiro, desde a década de 1980, por um projeto de intensificação do processo democrático. Tal processo passou a incorporar mais institucionalmente as questões de gênero na década de 1990 e, nas primeiras duas décadas do século XXI, questões ligadas a outros marcadores sociais da diferença, como orientação sexual, raça, etnia etc., que passaram a ser pensados e trabalhados nas políticas públicas educacionais e nas salas de aula de forma cada vez mais interseccional. Essas ações auxiliaram no processo de subjetivação fortemente marcado por uma ética do cuidado de si e dos outros e, consequentemente, na inclusão - ou pelo menos no combate à exclusão, à discriminação e à estigmatização - de grupos sociais que historicamente engrossam as estatísticas da desigualdade social e de mortalidade em nosso país, em uma necropolítica marcada fortemente pela atuação (ou inércia) do Estado brasileiro e corroborada pelos valores conservadores.

A eleição de Jair Bolsonaro para presidente em outubro de 2018, mesmo com todo o seu discurso abertamente antidemocrático, racista, machista, lgbtfóbico, anti-Estado laico e com projeto (ultra)neoliberal a partir de um expressivo apoio popular nas ruas, nas redes sociais e nas urnas (57 milhões de votos), pode dar a entender que essa ética de(s)mocrática tenha alcançado a hegemonia no contexto brasileiro. No entanto, apesar de muitos indícios em contrário, acreditamos, como Eliane Brum (2019), que nem todos os 57 milhões de pessoas que votaram em Bolsonaro no segundo turno da eleição concordam em todos os aspectos e ações de seu governo que foram apontados aqui, tendo o escolhido mais por uma aversão ao PT do que por afinidade com as ideias de seus/suas apoiadores/as. Um indício disso pode ser visto nos resultados de uma pesquisa do Datafolha ${ }^{46}$ divulgada no dia 7 de janeiro de 2019 apontando que, mesmo nesse ambiente convulsionado da sociedade brasileira, $54 \%$ da população responderam favoravelmente à pergunta “Educação sexual deve ser tema de aulas nas escolas?”. Para $71 \%$ da população, “temas políticos devem ser tema de aulas nas escolas".

\footnotetext{
${ }^{46}$ O Datafolha ouviu 2.077 pessoas em 130 municípios entre os dias 18 e 19 de dezembro de 2018. Para maiores informações sobre esta pesquisa acessar: $<$ https://g1.globo.com/educacao/noticia/2019/01/07/maioria-da-populacao-e-a-favor-da-educacao-sexuale-da-discussao-de-politica-nas-escolas-diz-datafolha.ghtml?fbclid=IwAR3V-2Ut92okxgdceZgSthPRo80ZHDT8qZ BBsO h590G2Ta7mROuTf5k>. Acesso em 8 mar 2019.
} 
Assumimos, então, que o caráter incontrolável do processo de significação ou do processo ensino-aprendizagem, incorporado de certa forma por aquelas políticas públicas para a diferença, se torna aqui um obstáculo inquebrantável para a nova agenda conservadora neoliberal, atuando politicamente como uma espécie de resistência política e ontológica. Outros eventos que apontam para o caráter incontrolável do processo educativo é que, mesmo com toda essa articulação internacional ultraconservadora, a "Primavera Secundarista" de 2016, que ocupou diversas escolas em todas as regiões do país, contou com forte presença de mulheres negras e LGBT nas ocupações ${ }^{47}$, inclusive entre as lideranças dessas ações (REAL, 2018; MARTINS, 2016), obstaculizando assim não só a efetivação dos interesses de grupos como o MESP e o Atlas Network como também o processo de de(s)mocratização, ao se oporem aos projetos de emendas constitucionais 241 na Câmara e 55 no Senado Federal, que congelam os investimentos públicos por 20 anos, ao Projeto de Lei $n^{\circ}$ 867/15, que visava implementar o Escola Sem Partido na educação brasileira. Além disso, nas ocupações estudantis havia pautas locais; muitas delas foram conquistadas. Danielly Real (2018) enumera muitas dessas conquistas estudantis, como a vitória contra a militarização das escolas em Minas Gerais; contra a fraude nas merendas em São Paulo; e a terceirização em Goiás; foram conquistadas verbas extras no Ceará para melhorar a merenda e reformar os prédios das escolas; no Rio de Janeiro, conseguiram acabar com a indicação política para o cargo de diretor, fazendo com que o processo fosse realizado por eleição direta; no Amazonas, conseguiram a implementação de uma lei que garante a liberdade de atuação dos grêmios estudantis, a chamada Lei do Grêmio Livre. Esses são exemplos da não linearidade do percurso dos acontecimentos em que as disputas políticas podem, sim, alterar os rumos da história.

\section{REFERÊNCIAS}

AUAD, Daniela. O curso Gênero e Diversidade na Escola como uma proposta de política igualitária. In: Os desafios da transversalidade em uma experiência de formação on line: curso Gênero e Diversidade na Escola. Org.: Fabíola Rohden, Leila Araújo, Andreia Barreto. Rio de Janeiro: CEPESC, 2008.

BAGGIO, K. G. Conexões ultraliberais nas Américas: o think tank norte-americano Atlas Network e suas vinculações com organizações latino-americanas. In: Encontro

\footnotetext{
${ }^{47}$ A ação política de ocupar as escolas ocorreu em todas as cinco regiões do país tendo como contexto mais geral além dos exemplos dos/as estudantes chilenos/as e argentinos/as nos anos anteriores, a Medida Provisória 746/2016 sobre a reforma do Ensino Médio, a PEC 241 na Câmara e da PEC 55 no Senado.
} 
Internacional da Anphlac, 12., 2016, Campo Grande. Anais eletrônicos... Campo Grande: UFMS, $2016 . \quad$ Disponível em http://anphlac.fflch.usp.br/sites/anphlac.fflch.usp.br/files/Katia\%20Gerab\%20Baggio\%20_ Anais\%20do\%20XII\%20 Encontro\%20Internacional\%20da\%20ANPHLAC.pdf. Acesso em 25 fev. 2019.

BALL, Stephen J. Diretrizes políticas globais e relações políticas locais em educação. Currículo sem Fronteiras, v. 1, n. 2, p. 99-116, jul./dez. 2001.

Performatividade, privatização e o pós-Estado do bem-estar. Educação \& Sociedade, v. 25, n. 89, p. 1.105-1.126, set./dez. 2004.

BALleStRIN, L. M. A. Rumo à teoria pós-democrática? 2017. Disponível em https://m.box.com/shared_item/https\%3A\%2F\%2Fapp.box.com\%2Fs\%2Fbm0d52sjav3e9 75hmz0sifjktrsz4too/view/279234863517. Acesso em 05 mar. 2019.

BRUM, Eliane. O homem mediano assume o poder. El País. 04 jan. 2019. Disponível em https://brasil.elpais.com/brasil/2019/01/02/opinion/1546450311_448043.html?fbclid=IwA R2wx7K5Iri8ENnDsVVIDms79uRz82ciDw5hoLWJohueTL4Cf8usVsQd8g8. Acesso em 08 mar. 2019.

BUTLER, Judith. Problemas de gênero: feminismo e subversão da identidade. Trad. Renato Aguiar. $2^{a}$ ed. Rio de Janeiro: Civilização Brasileira, 2008.

Cuerpos aliados y lucha política: hacia una teoría performativa de la asamblea. Trad. María José Viejo Pérez. Barcelona: Paidós, 2017.

CARREIRA, Denise; GONÇALVES, Ednéia. No centro da fogueira: gênero, raça e diversidade sexual nas eleições. Ação Educativa, 2018. Disponível em http://acaoeducativa.org.br/blog/2018/09/18/no-centro-da-fogueira-genero-raca-ediversidade-sexual-nas-eleicoes/. Acesso em 03 mar. 2019.

CÉSAR, Maria Rita de Assis; DUARTE, André de Macedo. Governamento e pânico moral: corpo, gênero e diversidade sexual em tempos sombrios. Educar em Revista, Curitiba, v. 33, n. 66, p. 141-155, 2017.

CORRÊA, Sônia. Ideologia de gênero: rastros e significados. Folha de S. Paulo, 05 nov. 2017. Disponível em https://agoraequesaoelas.blogfolha.uol.com.br/2017/11/05/ideologiade-genero-rastros-e-significados/. Acesso em 05 mar. 2019.

Eleições brasileiras de 2018: catástrofe perfeita? SPW. Disponível em http://www.cfemea.org.br/index.php/eleicoes/eleicoes-2018/4719-eleicoes-brasileiras-de2018-a-catastrofe-perfeita. Acesso em 08 mar. 2019.

Fala no painel Democracia, direito Sexuais e direitos reprodutivos: panorama internacional. Seminário Gênero Ameaça(n)do. UERJ, Rio de Janeiro, 28 fev. 2019. 
CRUZ, Thalles do Amaral de Souza. Diferença em disputa: os embates acerca do kit anti-homofobia (2004-2012). 143f. Dissertação (Mestrado em Educação) - Faculdade de Educação, Universidade do Estado do Rio de Janeiro. Rio de Janeiro, 2014.

"Olha, eu fiz o GDE, meu bem!": uma análise da capilaridade da política pública curricular no curso Gênero e Diversidade na Escola. $274 \mathrm{f}$. Tese (Doutorado em Educação) - Faculdade de Educação, Universidade do Estado do Rio de Janeiro. Rio de Janeiro, 2019.

DARDOT, Pierre; LAVAL, Christian. A nova razão do mundo: ensaio sobre a sociedade neoliberal. São Paulo: Boitempo, 2016.

FOUCAULT, Michel. Nascimento da biopolítica. Curso dado no Collège de France (1978-1979). São Paulo: Martins Fontes, 2008.

HEILbORN, Maria Luiza et aliae. Gestão de Políticas Públicas em Gênero e Raça/GPP-GeR - Módulo I: Políticas Públicas e Promoção da Igualdade. Rio de Janeiro: Cepesc; Brasília: Secretaria de Políticas para as Mulheres, 2010.

LACLAU, Ernesto. Emancipação e diferença. Rio de Janeiro: EdUERJ, 2011.

LOWENKRON, Laura; MORA, Claudia. A gênese de uma categoria. Entrevista com Rogério Diniz Junqueira. Centro Latino-Americano em Sexualidade e Direitos Humanos. 20 dez. 2017. Disponível em http://clam.org.br/destaque/conteudo.asp?cod=12704. Acesso em 04 mar. 2019.

LEITE, Vanessa. Sexualidade adolescente como direito? A visão de formuladores de políticas públicas. Rio de Janeiro: EdUERJ, 2013.

MACEDO, Elizabeth. Por uma leitura topológica das políticas curriculares. Arquivos analíticos de políticas educativas/Education policy analysis archives [online], v. 24, n. 26, p. 1-19, 2016.

As demandas conservadoras do Movimento Escola sem Partido e a Base Nacional Comum Curricular. Educação \& Sociedade, Campinas, v. 38, n. 139, p. 507-524, abr./jun. 2017.

Repolitizar o social e tomar de volta a liberdade. Educação em Revista [online], v. 34, p. 1-15, 2018.

MARTINS, Valeria. Sobre a participação das minorias nas ocupações estudantis: resistir contra as opressões! 18 nov. 2016. Disponível em: http://blogueirasnegras.org/2016/11/18/sobre-participacao-das-minorias-nas-ocupacoesestudantis-resistir-contra-as-opressoes/. Acesso em 04 mar. 2019.

OLIVEIRA, J. M. Cidadania sexual sob suspeita: uma meditação sobre as fundações homonormativas e neoliberais de uma cidadania de 'consolação'. Psicologia \& Sociedade; v. 25(1), p. 68-78, 2013. 
ONU Mulheres. Nota pública da ONU Mulheres Brasil sobre a garantia da educação sobre gênero na educação brasileira. Brasília: ONU Mulheres, 2016. Disponível em http://www.onumulheres.org.br/noticias/nota-publica-da-onu-mulheres-brasil-sobre-agarantia-da-educacao-sobre-genero-na-educacao-brasileira/. Acesso em 03 mar. 2019.

PARAÍSO, Marlucy Alves. Fazer do caos uma estrela dançarina no currículo: invenção política com gênero e sexualidade em tempos do slogan "ideologia de gênero". In: PARAÍSO, Marlucy Alves; CALDEIRA, Maria Carolina da Silva (Orgs.). Pesquisas sobre currículos, gênero e sexualidades. Belo Horizonte: Mazza, 2018. p. 23-52.

REAL, Danielly da Costa Vila. Primavera Secundarista: engajamento estudantil nas ocupações de Vitória - ES em 2016. 159f. Dissertação (Mestrado em Ciências Sociais) Departamento de Ciências Sociais, Universidade Federal do Espírito Santo. Vitória, 2018.

SERRANO-AMAYA, José Fernando. La tormenta perfecta: ideología de género y articulación de públicos. Sexualidad, Salud y Sociedad - Revista Latinoamericana, n. 27, p.149-171, dec. 2017.

SINTOMER, Yves. ¿Condenados a la posdemocracia? Nueva Sociedad, Buenos Aires, n. 267, Enero/Febrero 2017. Disponível em http://nuso.org/articulo/condenados-laposdemocracia. Acesso em 03 mar. 2019.

VARGAS, V. Los feminismos latinoamericanos y sus disputas por una globalización alternativa. In: MATO, D. (Org.). Políticas de identidades y diferencias sociales en tiempos de globalización. Caracas: Faces/UCV/Oceap/Cipost, 2003. p. 193-215.

Recebido: 05/03/2019

Aceito: 30/03/2019 